\title{
Prospects of Allelopathic Weed Management in Rice-Wheat Cropping System-A Review
}

\author{
Simranpreet Singh Bola ${ }^{1 *}$, Davinder Pal Singh Badwal ${ }^{2}$, Talwinder Singh ${ }^{3}$ \\ and Manpreet Kaur ${ }^{4}$ \\ ${ }^{1}$ Department of Agronomy, Punjab Agricultural University, Ludhiana, Punjab, India \\ ${ }^{2}$ Department of Agriculture Sciences, Sant Baba Bhag Singh University, \\ Khiala, Jalandhar, Punjab, India \\ ${ }^{3}$ Department of Agriculture, G.S.S.D.G.S. Khalsa College, Patiala, Punjab, India \\ ${ }^{4}$ Department of Agriculture and Farmer's welfare, Punjab, India \\ *Corresponding author
}

\section{A B S T R A C T}

\section{Keywords}

Crop rotation, Herbicide resistance, Weed smothering crops, Allelopathy, Weed management

\section{Article Info}

Accepted:

07 March 2020

Available Online:

10 April 2020
Rotation of rice-wheat cropping system is most popular in India due to its high productivity; however, these crops are highly infested by the varied weeds, thus farmers use various herbicides for their control. Resulting, this rotation consumes a large quantity of herbicides, which has resulted in severe problems like environmental and human health hazards; development of herbicide resistance in weeds etc. One of the emerging alternatives to overcome these problems is with the use of allelopathic strategies- an emerging field, including the use of weedsmothering crops for weed management and for the sustainability of agriculture. Various studies indicated that allelopathic strategies, including the use of smothering crops, could provide effective weed control in rice-wheat crop rotation and can manage weed populations at an economic threshold level without using any kind of chemicals. This may both eliminate/minimize the use of herbicides and eliminate all the major problems associated with herbicidal use.

\section{Introduction}

Allelopathy is a latest emerging field of science and the term 'Allelopathy' was coined by Prof. Hans Molisch, a German plant physiologist in 1937. Allelopathy is a term which includes any process involving secondary metabolites produced by microorganisms, plants, viruses and fungi etc. that alter the growth and development of agricultural and biological systems (Narwal,1994). Allelopathy focuses on becoming one of the strategic sciences to reduce the environmental pollution and to 
increase agricultural production in a sustainable mannerin the 21 st century. This term provides the basis for sustainable agriculture and currently allelopathy research is being done in various countries globewide and is receiving good attention from agriculturists and bioscientists as allelopathy offers great potential to (i) enhance agricultural production (food grains, vegetables, fruits, forestry etc.), (ii) reduce harmful effects of modern agricultural practices like multiple cropping, leaching losses from nitrogenous fertilizers, large scale indiscriminate use of pesticides etc. and (iii) sustain soil productivity and a pollutionfree environment for our forthcoming generations.

Allelopathy mainly works through releasing allelochemicals which are basically secondary substances, biosythesized from the metabolism of carbohydrates, fats and amino acids and stored in the plant cells and do not alter the cell activities. However, after their release from the plant cells (through volatilization, leaching root exudates and decomposition of biomass), these allelochemicals then start influencing the organisms (plants, pathogens, insect pests, etc.) by coming in contact(Rice, 1984). Sustainable agriculture emphasizes on optimal crop production with minimal external inputs, reducing dependence on chemical inputs (like fertilizers and pesticides) and substituting them with internal resources and relying on sustainable practices which could maintain the system productivity over long periods.

In India, rice-wheat rotation became most popular owing to its high yields; however, these crops are highly infested by the weeds, thus farmers use various herbicides for their control. Resulting, this rotation consumes a large quantity of herbicides, which has resulted in severe problems like environmental and human health hazards; development of herbicide resistance in weeds. The latest options to overcome these problems are the use of allelopathic strategies, covering the use of weed-smothering crops for weed management and for the sustainability of agriculture (Narwal, 2000).

Research has shown that allelopathy may provide a basis to achieve the goals of sustainable agriculture and also, being an important phenomenon in agriculture field; its thorough and deep research is also important for sustaining agriculture (Choi, et al., 1995 and Ramakudzibga, 1991). Hence, future weed control practices must minimize/reduce the application of herbicides and use allelopathic strategies and other environmental practices for weed management.

\section{Influence on weed control by utilizing smothering crops}

The weed-smothering crop plants hinders the growth of weeds through interference, that is, via competition and allelopathy. (Narwal,1996) has listed some of the important weed-smothering crops for summer viz., sorghum, sudan grass, pearlmillet, hemp, soybean, cowpea, alfalfa and winter (barley, rye, oat, buckwheat, sweet clover, rapeseed) seasons. In field studies during summers, the results showed that the summer fodder crops significantly influenced the weed population throughout the growing season.

The crops had a variable effect on the density of broadleaved and grassy weeds. Generally, suppression was greater in the former than in later weeds. The removal of wheat straw from the experimental plots statistically decreased the weed dry matter when compared with straw burning or soil incorporation methods. Pearlmillet and maize caused a greater reduction in the dry matter than the legume fodders and among cereals, Pearlmillet 
(Bajra) resulted in the maximum reduction of 88.8 to $96.1 \%$ in weed dry matter production. The inclusion of smothering crops in cropping system with a residual effect like pearlmillet may provide weed management in the subsequent rice crop without application of herbicides. In north India, the winter season (November to March) is generally dry; resulting, weeds are a major problem in irrigated agriculture. In irrigated areas, wheat is the main crop grown, hence, herbicides are used extensively on large scale, which has resulted in the development of resistance in Phalaris minor to isoproturon herbicide only in rice-wheat rotation (Malik and Singh, 1995) because maximum herbicides are used in rice-wheat rotation; as it produces maximum foodgrains (12.0 to 15.0 t/ha in an 8 -month crop period). It is very likely that in the foreseen future many weed spp. may also develop such resistance.

Worldwide, several weed species have become resistant to varied herbicides, hence it is a major problem for weed scientists. Soil incorporation of rice stubble decreased the weed density compared with the control; wheat and berseem decreased the weed population, whereas oat and lentil increased it, this might be due to the root exudates of later crops might have stimulated the germination of weed seeds. Berseem crop performed very well in field by smothering the broad-leaved weeds and caused a $52.39 \%$ suppression when compared with wheat $(16.76 \%)$ and oat crop caused a slightly greater suppression in the weed population than lentil as well.

\section{Utilizing non-chemical weed management in rice-wheat rotation}

In India, herbicide resistance has started developing in biotypes of Phalaris minor, a major weed of rice-wheat rotation; hence, in the coming future more such weeds may develop herbicide tolerance; therefore, chemical-based weed management may not be sustainable in the future. Thus, the use of allelopathic strategies seems to be the one way for managing weeds to achieve sustainable rice-wheat rotation. The studies conducted with summer and winter crops have amply demonstrated a greater potential of smothering crops to manage the weeds without the use of herbicides in the rotation.

Among the fodder crops, pearlmillet has the fastest growth rate and produces the highest biomass per day, hence, pearlmillet could be grown during this fallow period (mid-April to the end of June) to smother the summer weeds as well as to control weeds in the subsequent rice crop through its residual suppression effect. Similarly, double cropping of rice-barley reduced seed occurrence in rice crop by $30 \%$ as compared with a single crop of rice and it was attributed to allelopathic effect of barley residues (Choi, et al., 1995). Further, to improve soil fertility and fodder quality, the mixture of pearlmillet and clusterbean may be grown.

To reduce the infestation and growth of broadleaf and grassy weeds in rice fields, the egyptian clover (Trifolium alexandrinum L.) and oats (Avena sativa L.) may be grown successfully. The former crop may be more effective in controlling weeds through its frequent cutting for fodder that may prevent seed setting in various weeds. Therefore, cultivating berseem for 2-3 years after rice may significantly reduce the weed population. Furthermore, the bioassays have indicated that $10 \%$ aqueous extract of rice straw completely controlled the Phalaris minor seedling growth. These rotations based on weed-smothering crops of summer (pearlmillet) and winter (oat, Egyptian clover) seasons may solve the problems of weed infestation in rice and wheat cropping system (Table 1). 
Table.1 Three-year long rice-wheat rotations have been made to manage the weeds and minimize the use of different herbicides

\begin{tabular}{|c|c|c|c|}
\hline Target crop \# & & Rotations & \\
\hline Rice & Pearlmillet-rice-wheat & Pearlmillet-rice-wheat & Pearlmillet-rice-wheat \\
\hline Wheat & Pearlmillet-rice-oat & Pearlmillet-rice-berseem & $\begin{array}{l}\text { Fallow (30days)-rice- } \\
\text { wheat }\end{array}$ \\
\hline Wheat & $\begin{array}{l}\text { Pearlmillet-rice- } \\
\text { berseem }\end{array}$ & Fallow(30days)-rice-oat & Pearlmillet-rice-wheat \\
\hline
\end{tabular}

\# Crop in which weed management is required. Note: Figure in parenthesis indicates the duration of fallow period

These studies indicated that allelopathic strategies, including the use of smothering crops, could provide effective weed control in rice-wheat rotation. Although these crops do not provide complete weed control but they can manage weed populations at an economic threshold level without using any kind of chemicals.

This may either eliminate/minimize the use of herbicides or eliminate all the major problems associated with herbicidal use. These studies have shown the order of weed suppression in summer crops as pearlmillet > maize > sorghum $>$ clusterbean $>$ cowpea and in winter crops as berseem > oat > lentil > wheat.

\section{References}

Choi, C. D., Moon, B. C., Kim, S. C., and Oh, Y. J. (1995). Korean Journal of Weed Science. 15:39-44.

Chou, C.H. (1983). Allelopathy in agroecosystems. In: Allelochemicals and Pheromones. (Eds., C.H. chou and G.R. waller). pp. 27-64. Taipei, Taiwan: Institute of Botany, Academra Sinica.

Malik, R. K. and Singh, S. (1995). Litter canarygrass (Phalaris minor) resistance to Isoproturon in India. Weed Technol. 9:419425.

Narwal, S. S. (1994). Allelopathy: Future role in weed control. In: Allelopathy in Agriculture and Forestry, Narwal, S. S. and Tauro, P., Eds., pp. 245-272. Scientific Publishers, Jodhpur, India.

Narwal, S. S. (1996). Potentials and prospects of allelopathy mediated weed control for sustainable agriculture. In: Allelopathy in Pests Management for Sustainable Agriculture, Narwal S. S. and Tauro P., Ed., pp. 23-66. Scientific Publishers, Jodhpur, India.

Narwal, S.S. (1994). Allelopathy in Crop Production. Scientific Publishers, Jodhpur, India.

Narwal, S.S. (2000). Weed Management in Rice: Wheat Rotation by Allelopathy. Critical Reviews in Plant Sciences, 19(3):249-266.

Ramakudzibga, A.M. (1991). Allelopathic effects of aqueous wheat (Triticum aestium L.) straw extracts on the germination of eight arable weeds found in Zimbabwe. Zimbabwe Journal of Agricultural Research, 29: 77-79.

Rice, E.L. (1984). Allelopathy. 2nd edition. Academic Press, New York.

\section{How to cite this article:}

Simranpreet Singh Bola, Davinder Pal Singh Badwal, Talwinder Singh and Manpreet Kaur. 2020. Prospects of Allelopathic Weed Management in Rice-Wheat Cropping System-A Review. Int.J.Curr.Microbiol.App.Sci. 9(04): 670-673. doi: https://doi.org/10.20546/ijcmas.2020.904.081 